\title{
THE IDENTITY OF THE NURSING ACADEMIC: BETWEEN EDUCATION AND RESEARCH ${ }^{1}$
}

\author{
Mariela Aguayo González², Montserrat Castelló Badia3 , Carles Monereo Font ${ }^{4}$
}

\footnotetext{
${ }^{1}$ Part of the doctoral dissertation - The identity of nursing academics: a process under construction, funded by a grant from Formació d'Investigació Blanquerna, to the Ph.D. candidate.

2 Ph.D. candidate, Facultad de Psicología y Ciencias de la Educación y del Deporte de la Universidad Blanquerna. Barcelona, Spain. E-mail: maguayog@yahoo.com

${ }^{3}$ Ph.D. Senior Professor, Facultad de Psicología y Ciencias de la Educación y del Deporte de la Universidad Blanquerna, Ramón Llull. Barcelona, Spain. E-mail: MontserratCB@blanquerna.url.edu

${ }^{4}$ Ph.D. Full Professor, Department of Psychology, Universidad Autónoma de Barcelona. Barcelona, Spain. E-mail:carles. monereo@uab.cat
}

\begin{abstract}
This study aimed to analyze how nurses represent their role as nursing academics and their conceptions, strategies and feelings involved in teaching-learning and research in nursing. A qualitative study was conducted. To achieve this goal, a semi-structured interview was carried out with seven nurses who worked as teachers and researchers at a university in Barcelona, Spain. The data were analyzed through categories validated in a previous study with the support of The Atlas Ti program. The results evidenced that nurses are less equipped to develop the researcher role, and that the profession is not justified without a close relationship between nursing theory and practice. The nursing academics look for a balance between teaching and research and they also wish to promote the development of models and theories in their own discipline.
\end{abstract}

KEYWORDS: Education, nursing. Research. Nurse's role.

\section{A IDENTIDADE DO ACADÊMICO DE ENFERMAGEM: ENTRE O ENSINO E A PESQUISA}

RESUMO: O estudo teve como objetivo analisar como as enfermeiras representam seu papel como acadêmicas de enfermagem, suas concepções, suas estratégias e seus sentimentos envolvidos nos processos de ensino-aprendizagem e pesquisa na enfermagem. Realizou-se uma pesquisa qualitativa. A coleta de dados foi através da entrevista semiestruturada aplicada a sete enfermeiras que trabalham como docentes e pesquisadoras em uma universidade de Barcelona, Espanha. Os dados foram analisados através de categorias validadas em um estudo anterior com o apoio do programa de ATLAS ti. Os resultados evidenciarem que as enfermeiras sentem-se menos preparadas para desenvolver o papel de investigadoras e que a profissão não se justifica sem uma estreita relação entre a teoria e a prática de enfermagem. As acadêmicas de enfermagem buscam equilíbrio entre a docência e a pesquisa e sentem-se desafiadas a desenvolver teorias e modelos em sua disciplina.

PALAVRAS CHAVE: Educação em enfermagem. Pesquisa. Papel do profissional de enfermagem.

\section{LA IDENTIDAD DEL ACADÉMICO DE ENFERMERÍA: ENTRE LA DOCENCIA Y LA INVESTIGACIÓN}

RESUMEN: El estudio tuvo como objetivo analizar cómo las enfermeras representan su rol como académicos de enfermería, sus concepciones, sus estrategias y los sentimientos involucrados en los procesos de enseñanza y aprendizaje e investigación en la enfermería. Se realizó un estudio cualitativo, y la recolección de datos fue a través de una entrevista semi-estructurada a siete enfermeras que trabajan como docentes e investigadoras en una universidad de Barcelona, España. Los datos se analizaron a través de categorías validadas en un estudio anterior con el apoyo del programa Atlas Ti. Los resultados evidenciaron que las enfermeras se sienten menos preparadas para desarrollar el rol de investigador, y que la profesión no se justifica sin una estrecha relación entre la teoría y la práctica de la enfermería.Los académicos de enfermería buscan un equilibrio entre la docencia y la investigación y se sienten desafiadas a desarrollar teorías y modelos en su propia disciplina.

PALABRAS CLAVE: Educación en enfermería. Investigación. Rol de la enfermera. 


\section{INTRODUCTION}

The current and future challenges in the professionalization of nursing pose the need for an educational process based on suitability, excellence and quality, which allows nursing to establish itself as an autonomous profession among the health care disciplines. ${ }^{1}$ This process demands the creation of models and theories to sustain the profession, and the development of research to enhance knowledge in the discipline. Therefore, to achieve professionalization, nursing needs to offer knowledge on the area of study, scientific foundations to sustain it, theories and models that integrate the knowledge bases and a considerable amount of studies on the study phenomenon, developed by members of the community. ${ }^{2}$

What characterizes nursing is the use of understanding, interested in discovering the intention of the interaction, further examining health rites and beliefs from individual and collective perspectives. ${ }^{3-4}$ Therefore, when considering nursing research, the qualitative paradigm is the most appropriate method to understand the studied phenomenon. The research problem is approached comprehensively and from within, and the knowledge resulting from this kind of studies permits effective interventions that are truly based on people's needs..$^{5-6}$ Nevertheless, the nurses still lack knowledge on the use and application of this method in the discipline.

With regard to teaching, the literature agrees that integration between theory and practice is necessary with a view to enhancing students' learning. ${ }^{7}$ In the current nursing course curricula, however, a strong influence from the biomedical model is still perceived and, as a result, a clear disconnection between theory and practice. ${ }^{8}$ Consequently, curricular changes are needed to guide the teaching of this profession.

In this context, on October $30^{\text {th }} 2007$, the decree was published in Spain that ordered university teaching to comply with the European Higher Education Area. This decree enables nurses to obtain an undergraduate degree, increasing the number of credits from 180 to 240 and extending the length of the program by one year. ${ }^{9}$ This puts an end to a three-year degree that did not permit further aspirations towards academic and especially research qualification, and provides an interesting impulse for nursing teaching and research. The roles of nurses are multiplied and made increasingly complex. As a result, more nurses engage in teaching, further research is developed and the need for complementary education emerges in the form of Master's and Ph.D. programs in nursing.

Changing the view of what should be taught in nursing and how is not an easy task. A more or less in-depth reflection on the facets patient care requires is not sufficient; nor is the change of some teaching methods and strategies, aiming for a more global and systemic analysis of the patients' reality. The analysis of the nurses' own emotions and feelings associated with being a competent professional is not enough either. To promote a nursing education that is less burdened by the tradition of nurse practitioners and more in accordance with the idea of a holistic and systemic care, nurse educators need to be focused on, as well as all aspects that constitute their identity. ${ }^{8}$ In teaching, the teachers are continuously producing specific, tacit, personal and non-systemized knowledge which, in relation to their implicit beliefs and theories, condition the construction process of their identity as teachers. ${ }^{10}$

The construction process of the nurse's identity starts with the course, and is consolidated during professional practice; nevertheless, the construction of an identity as a nurse teacher supposed a less institutionalized trajectory, which starts with the access to college teaching, entailing new challenges, such as the need to create and disseminate advanced knowledge about the nurses' role and functions. This implies the possibility to work in areas they were hardly prepared for in their undergraduate program. On the other hand, as mentioned, the researcher role strongly appears in nursing studies and, in the current context, constitutes a new dimension that adds up to teaching and, in turn, requires the construction and development of specific identity elements.

Hence, studying the identity of nursing academics implies centering on its construction process and constituent elements. Thus, teaching identity is considered as the set of representations of oneself which are constructed in education 
and professional practice contexts, and which are expressed through discourse, procedures and emotions, before, during and after professional practice. ${ }^{11}$ From this perspective, the teacher's and, by extension, the researcher's identity, results from an interaction between personal experience and the social, cultural and institutional environment in which it develops every day; and relates to the way in which teachers and researchers define themselves towards themselves and other people. ${ }^{12}$

Nevertheless, there is a lack of studies that have focused on the analysis of nursing academics' identity* in the Spanish context at this time of change, and on how it is modified or constructed to respond to the new challenges of the profession.

In this study, we intend to contribute to complete this lack of knowledge and to explore the identity of nursing students. More concretely, our objectives were to analyze how the nurses represent their role as nursing academics, their conceptions, strategies and feelings involved in the teaching and learning processes and in nursing research.

\section{METHOD}

A qualitative and cross-sectional research with a descriptive-interpretative design was developed in accordance with the principles of the Grounded Theory, based on the premises of Glaser and Strauss.

In addition, the research complied with the ethical principles of research involving human beings, in line with the Helsinki declaration, and received approval from the ethics committee at Facultat de Psicología, Ciències de l'Educació i l'Esport Blanquerna de la Universidad Ramon Llull on October $24^{\text {th }} 2012$, under registration number 241012/DP. The participants were in- formed about the study characteristics and objectives and then signed the informed consent form to agree with their participation and with the anonymous use of their data for the sole purpose of this research.

\section{Participants}

The participants were seven nurse teachers and researchers from the school of nursing of a private university in Barcelona, who were selected according to the following inclusion criteria: being an active nurse teacher at the university and having finished or being currently enrolled in Master's or Ph.D. programs. Thus, the sample consisted of two novel nurses with less than five years of teaching experience, and five nurses who had been involved in academic functions for more than ten years.

The information was collected through a semistructured interview, including five questions to identify how the nurses define themselves in the role of nursing academics; how they describe their teaching, and what are the strategies and the main concerns in the teaching and learning processes and in nursing research. The interviews took between 45 and 60 minutes and were audio-recorded, followed by content analysis with the help of the atlas ti software. ${ }^{13}$ Therefore, a hermeneutical unit was elaborated which contained the seven interviews, which were first coded based on three central categories that derive from the theoretical consideration of the teacher's identity, including three dimensions: conceptions, strategies and feelings. ${ }^{14}$ The second phase resulted in a list of new codes deriving from the previous phase, which was submitted to a triangulation process by two experts on the theme teacher identity. Based on these, two new categories were established, one related to the role of researcher and the other to the nursing teaching and learning process (Figure 1).

* Corresponds to nursing professionals dedicated to higher education who have graduated from or are enrolled in an M.Sc. or Ph.D. program, and also develop nursing research as part of their function. 
Figure 1 - Definition of categories that emerge from the qualitative analysis. Barcelona, Spain, 2012

\begin{tabular}{|l|l|l|}
\hline Categories & Definition & Codes \\
\hline Role of researcher & $\begin{array}{l}\text { The role the nursing academic with an } \\
\text { M.Sc. or Ph.D. degree assumes and/or is } \\
\text { developed or has participated in nursing } \\
\text { research processes. }\end{array}$ & $\begin{array}{l}\text { Conceptions about research. } \\
\text { Difficulties in the research process. } \\
\text { Research strategies. } \\
\text { Concerns with research. } \\
\text { Feelings associated with research. }\end{array}$ \\
\hline $\begin{array}{l}\text { Teaching and learning process } \\
\text { of nursing }\end{array}$ & $\begin{array}{l}\text { Corresponds to teaching centered on care, } \\
\text { in which neither the work nor the product } \\
\text { but the process is prioritized. The teacher } \\
\text { is interested in the student and what mat- } \\
\text { ters most is to know who the student is and } \\
\text { how (s)he will learn how to learn. Thus, the } \\
\text { final goal of learning will be patient care. }\end{array}$ & $\begin{array}{l}\text { Conception of teaching and learning. } \\
\text { Teaching strategies and resources. } \\
\text { Concerns with teaching. } \\
\text { Role as nursing academic. } \\
\text { Feeling associated with teaching. }\end{array}$ \\
\hline
\end{tabular}

\section{RESULTS}

Based on the information, that is, the participants' discourse in the interviews, in total, 12 codes were established for the abovementioned categories. Figure 2 shows the codes for each category, the total number of citations per code and the percentage it represents in each category. As observed, the most frequent codes in the participants' discourse were related to the concerns with teaching, followed by the conceptions about the students. With regard to the role of the researcher, the conceptions about research stand out, which are closely linked to the concerns with the meeting of this role as well.

Figure 2 - Distribution of codes in relation to the categories. Barcelona, Spain, 2012

\begin{tabular}{|c|c|c|c|}
\hline Categories & Codes & Number of citations & Percentage \\
\hline \multirow[t]{5}{*}{ Role of researcher } & Conceptions about research. & 19 & $10.2 \%$ \\
\hline & Difficulties in the research process. & 7 & $4 \%$ \\
\hline & Research strategies. & 7 & $4 \%$ \\
\hline & Concerns with research. & 10 & $5.7 \%$ \\
\hline & Feelings associated with research. & 9 & $5.1 \%$ \\
\hline \multirow{7}{*}{$\begin{array}{l}\text { Teaching and learning } \\
\text { process of nursing }\end{array}$} & Conceptions about the students. & 20 & $11 \%$ \\
\hline & Conception of teaching and learning. & 16 & $9.1 \%$ \\
\hline & Link between theory and practice. & 9 & $5.1 \%$ \\
\hline & Teaching strategies and resources. & 19 & $10.8 \%$ \\
\hline & Concerns with teaching. & 22 & $12.5 \%$ \\
\hline & Role as nursing academic. & 18 & $10.2 \%$ \\
\hline & Feeling associated with teaching. & 19 & $10.8 \%$ \\
\hline \multicolumn{2}{|l|}{ TOTAL } & 175 & $100 \%$ \\
\hline
\end{tabular}

Next, the most highlighted results for each category are presented in detail. The participants' declarations are presented with the letter $\mathrm{P}$, followed by a number from 1 to 7 for the sake of distinction.

\section{Role of researcher}

The role of the researcher was constituted based on five codes, presented next. 


\section{Conceptions about research}

All of the interviewees value the need to incorporate research as a key activity in their work as nursing academics, but also agree that this role is still incipient and has hardly been defined. This supposes that research remains linked - or subject - to other professionals and epistemological spheres that make it difficult for nursing to advance towards professional autonomy. The following citation clearly exemplifies this consideration:

when we studied, we did not see the teachers doing research. Today, the students see us, so I think this referent is important, I've never seen my teachers doing research or participating in research, or adopting that attitude, right?, today our students know that, today, all over the world, we are doing theses or Master's programs or ... there are research areas, and they know where we stand and, in addition, they know and we explain to them what we are doing, organizing meetings and there are also specific subjects (P1).

\section{Feelings associated with research:}

The feelings associated with research the interviewees mention are mainly negative, and take the form of insecurity and uncertainty or fear. This insecurity is manifested in view of different aspects, such as the lack of methodological tools or lack of knowledge on scientific terms, as shown in the following example.

As if it were fear of the unknown one could say, because actually research as a whole is unknown to me, although I have been involved for a year, but a year in research is like nothing (P4).

\section{Research strategies}

In general, all of the interviewees signaled the qualitative method as research strategies, given that it allows them to collect people's experiences. It is clear to the nurses in our sample that the qualitative research strategies favor a relationship of help and proximity, and are useful to tighten the bond with the patient, differently from the quantitative methods, which they consider more appropriate for biomedical studies, besides the fact that they do not reflect people's needs. In the following citation, the interviewee represents this idea by signaling that she feels more qualitative than quantitative.
I am less quantitative and more qualitative, I think it's very important to value well, my course help relation therapeutic communication attribute more value to the aspects of the disease experience than knowing the disease itself, right? I think it is very important for nursing to move forward in that area because there is a lot of research at the biomedical level, many papers written but, from the qualitative perspective of the experience of the health and disease process, not much exists (P1).

\section{Concerns and difficulties involving research}

The relations with the tutor-director and the approval or acknowledgement of peers were the concerns and difficulties the interviewed nurses mentioned first.

To a lesser extent, the general aspects of the research process, such as the organization of time, the availability of informants who comply with the profile or of sufficient economic resources to reach the end of the process were also part of the common concerns, as evidenced in the following excerpts.

In my doctoral dissertation, what I was most concerned with was to find informants, according to the profile I needed newly arrived people in situations that sometimes involved legal or job conflicts, their administrative situation in the country, I was concerned with that, in fact I had to change the data collection techniques, because my initial idea was to do, ... was to organize focus groups and I had to do interviews and be very flexible (P1).

As regards the teaching and learning process, the interviewees' answers are summarized in five codes, represented next.

There are two postures related to the nurses' conception about the students. The first puts the students forward as responsible for their learning and also for their learning problems. The teacher stands at the margin and remains stable while the students have changed in recent years. The second posture implies the consideration that the teacher's actions mediate the students' learning and that, therefore, this is an interactive process that questions both.

[...] what I have noticed is that there attitudes, kind of, more brazen, that is, which may not show the necessary restraint, like getting up in the middle of the class and go away without any respect, neither for their colleagues nor for the teacher, they are freer, 
negatively, but also freer to express their discomfort or disagreement, or they are more critical, perhaps neither coherently nor logically, but more critical, not constructive but more critical, and they express it, perhaps they used to be critical but remained silent, now they are more.... if they used to be passive, they're more active now $[\ldots]$ (P2).

The following citation exemplifies the second posture we referred to: [...] I think that, if the students talk, they may be talkative, but something is related to the feedback they receive from the teacher [...] (P3).

\section{Conception of teaching and learning}

As regards the conception of teaching and learning, the interviewed nurses manifested the importance of the connection between theory and practice in nursing teaching. From their perspective, the profession is not justified without a close relation between the theoretical contents and the hospital practices, which is why they are periodically updating their classes and use methodologies with clinical cases that favor authentic teaching. The following example illustrates this general conception that, in addition, entails the need for teachers to be in direct contact with the care reality.

[...] well, trying to work with many clinical cases and really cases that depart from the practice itself, right?, because that indicated that it's important ... [recycling], in my case it's impossible now because of the management..., the mobility is very difficult to $m e$, as I used to do earlier in recycling. Since I'm on the management board, I haven't been able to do that but these contacts in practice are very useful to make it very clear that these cases have not been invented, it's not purely theory, but they are actual situations in practice whose reflections they can see [in class] (P1).

\section{Feelings associated with teaching}

The aspect that often makes them feel afraid and anguished is the ability to motivate the students. The answers showed that the nurses feel strongly responsible for complying with this objective, as shown in the following citation:

man, I am concerned with not being able to motivate them enough, I am concerned because this, right? That it won't make them sufficiently interested, that the class won't be sufficiently motivating, right? (P3)

\section{Teaching strategies and resources}

The interviewed sample highlights the solution of clinical cases as the most effective teaching and learning strategy to approximate the students with the hospital reality.

The cases, the reality, that is, after introducing the minimal theoretical knowledge they need to understand something, then we take real or simulated cases, it depends on the circumstances and the work to solve them (P3).

\section{Role as nursing academic}

The interviewed nurses clearly distinguished between the teaching and research branch in their academic role. The teaching role refers to the facilitation of learning, to monitoring. Students are the main responsible for their learning but they mediate this process, offering the help needed to enhance it. The following excerpt evidences this conception:

well, the role is to facilitate learning eh... even though there are very big groups of students, but I think it's not so much to give classes, but to try and make the student get involved and participate that is difficult, when there are so many people in the classroom (P1).

They clearly indicate the research branch as part of their academic role, a branch that is essential to develop studies that allow them to gain disciplinary and professional autonomy. [...] and, so, I would like to grow in that sense and mainly make the discipline grow in that sense, to be able to do nursing research and help other nurses with my example and that they say I pay attention to what that teacher taught me what nursing research is, but I'm just at the very start (P6).

In summary, and focusing on the aspects that constitute the identity of the nursing academic, we may say that it combines the roles of teacher and researcher. As regards the researcher identity, the nurses feel much less prepared for this performance. They think that they still receive great influence from other professions, such as medicine, which prevents them from developing as an autonomous discipline that is interested in other research foci. This reality bothers them and, in addition, they mention great insecurity and fear in view of the idea of undertaking a research project autonomously. Although they find great 
potential in the qualitative paradigm to do nursing research, it is also true that, as they have developed research under the wings of other professionals, mainly physicians, for many years, it is difficult for them to uproot the feeling of inferiority this professional context creates. Nevertheless, it is clear that, from their perspective, the characteristics of the qualitative method are the most appropriate to approach the research problem, as they allow them to study the people's experiences from a holistic perspective.

Concerning the teaching identity, the nurses' conceptions, feelings and strategies in our sample can be summarized as follows. They acknowledge the presence of a gap between theory and practice, and signal that the profession is not justified without a close relation between the theoretical and practical contents, a situation they see as a problem. Thus, one of the strategies that would allow them to reduce this gap would be the use of personal experiences and of clinical cases as learning methods. As regards the feelings teaching arouses, they mention anguish when they are unable to motivate the students. On the other hand, the need to teach classes in subjects they are not prepared for creates great insecurity and fear.

\section{DISCUSSION}

As mentioned, the lack of studies about the preparation of nurse teachers ${ }^{8,10}$ attest the need to go deeper into aspects of the teaching and learning process, but closely linked to what the nurse teachers think about this process. Promoting studies that favor the development of its own theories and models will enhance the consideration of nursing as an autonomous discipline, centered on satisfying the real needs of people as a distinctive aspect of the profession. At bottom, our study intends to contribute to the progressive achievement of this challenge. In that sense, some earlier studies have highlighted the need for a solid nursing theory that challenges the medical models and that permits justifying the role of nurses. ${ }^{8,16}$ Similarly, the use of a theoretical framework in nursing teaching serves as the source of clinical knowledge, as well as the base for professional autonomy. ${ }^{6}$ Nevertheless, the interest in the creation of theories and models has also supposed, as a consequence, a heterogeneous development of nursing theory at the international level, which has irretrievably brought about a transformation in the concept as well as the application of care practice. ${ }^{2}$

In our study, we intended to discover how the nurses represent their role as nursing academics, as well as to analyze the conceptions, feelings and strategies used in the teaching and learning and research process in nursing.

As regards the practice of the research role, the results indicate that, for the nursing academics in our sample, research practice supposes a series of challenges that are related to the acknowledgement of the virtues of the qualitative paradigm to do nursing research, but also efforts to understand and take control of this method. This firm commitment to a research focus that favors the qualitative analysis as the most appropriate to understand the true needs of people who are vulnerable was also indicated by Victoria Henderson, who observed in the International Council of Nurses (ICN), "[...] that nursing looks into people's subjectivity to identify their needs". ${ }^{5: 20-21}$ It is a profession that, like the qualitative method, works with an inductive method, putting it in a privileged position to explain the world of patients and their families to other people. ${ }^{5-6}$

Concerning the teaching role and everything involved in the teaching and learning process, the results manifested that the integration between theory and practice is fundamental for the participating nurses to raise the standards of the discipline. In that sense, they are willing to overcome what some authors have identified as the metaphor of the "gap between theory and practice". For a long time, this metaphor has influenced nursing education, raising an obstacle for our students' learning. ${ }^{17}$ Some initiatives, such as the creation of a nursing role that combines the educative with the clinical role, can contribute to reduce this gap, besides the existence of curricular designs that permit the synchronization of theoretical contents and clinical practice, something that seems particularly relevant in our study.

In this context, different authors have raised innovative proposals for care teaching, focused on authentic education. This teaching is based on knowledge about the person as a holistic and complete human being, and the care activities represent the person's true needs. Therefore, nursing education should be focused on having the students experience and grow in care as part 
of their teaching. ${ }^{4}$ In that sense, it seems that, for this sample as well, personal experiences and clinical cases seem to be the methods that most favor the achievement of student learning. Anecdotes, examples and analogies provide significant learning when used as part of an interactive method in nursing teaching. ${ }^{10}$

\section{CONCLUSION}

In conclusion, the nursing academics who participated in our study build their identity between teaching and research, despite the difficulties this entails, as mentioned in the results. The application of the Bologna process and the creation of the European Higher Education Area allow them to position themselves as professionals with greater academic opportunities; nevertheless, it also entails further requirements to recycle and maintain a research level in accordance with the standards of other health professionals. Consequently, they consider that it is important to have continuing education as an essential condition for the proper practice of their role. In addition, as professionals who are reappearing with further attributions in the academic sphere, nursing research needs to grow through the development of theories and models that contribute to the development of autonomous professionals who are interested in the holistic wellbeing of both healthy and ill people.

We are aware that the study comes with limitations, deriving from the restricted number of participants as well as the method used, although it represents a first advance in a practically unexplored research area. In that sense, future studies can not only broaden the sample to other contexts, but also look at the practices the professionals develop in teaching as well as in research. Monitoring the aspects that most concern them or the critical incidents they discuss in their classes as well as in their research would be a complementary approach to this study and would permit understanding how the academics' identity is updated and materialized in specific situations and activities.

\section{REFERENCES}

1. Gutierrez L. Formación profesional factor determinante en el ejercicio profesional con calidad en enfermería. Rev Enferm Inst Mex Seguro Soc. 2008 Sept-Dic; 16(3):121-25.
2. González E, Arras M, Moriel L. La profesionalización en enfermería: hacia una estrategia de cambio. Tecnociencia Chihuaha. 2012 Ene-Abr; 6(1):1-8.

3. Bernal M, Ponce G. Propuesta para la enseñanza del cuidado en enfermería. ENEO-UNAM. 2009 Ene-Mar; 6 (1): 33-41.

4. Pinto A. El cuidado en el proceso de enseñanza y aprendizaje. In: Grupo de cuidado. El arte y la ciencia del cuidado. Colombia (CO): Universidad Nacional de Colombia; 2002. p. 45.

5. De la Cuesta C. Naturaleza de la investigación cualitativa y su contribución a la práctica de enfermería. Metas Enferm. 2006 Jun; 9(5):50-5.

6. De la Cuesta C. La investigación cualitativa y el desarrollo del conocimiento en enfermería. Texto Contexto Enferm. 2010 Oct-Dic; 19 (4):762-6.

7. Hatlevik I. The theory-practice relationship: reflective skills and theoretical knowledge as key factors in bridging the gap between theory and practice in initial nursing education. JAN. 2011Abr; 68(4):868-77.

8. Aguayo M, Monereo C. La enfermera formadora: la construcción de una nueva identidad profesional. Invest Educ Enferm. 2012 Sept-Dic; 30(3):398-405.

9. España. Real decreto 1393/2007, del 29 de Octubre 2007 (ES). Se establece la ordenación de las enseñanzas universitarias oficiales. Boletín oficial del estado, España, 30 de Octubre, 2007. [acceso 5 Feb 2013]. Disponible en: http:/ / www.boe.es/boe/ dias/2007/10/30/pdfs/A44037-44048.pdf

10. Backes VMS, Moyá JLM, Prado ML. Proceso de construcción del conocimiento pedagógico del docente universitario de enfermería. Rev Latino-Am Enferm [online]. 2011 Mar-Abr [acceso 14 Dic 2013]; 19(2). Disponible en: http://www.scielo.br/pdf/ rlae/v19n2/es_26.pdf

11. Monereo C, Badía A. Los heterónimos del docente: identidad, selfs y enseñanza. In: Monereo C, Pozo JL. La identidad en psicología de la educación: enfoques actuales, utilidad y límites. Madrid (ES): Narcea; 2011. p. 57-75.

12. Beijaard D, Verloop N, Vermunt JD. Teachers' perceptions of professional identity: an exploratory study from a personal knowledge perspective. Teach Teacher Educ. 2000 Oct; 16(7):749-64.

13. Muñoz J, Sahagún M. Análisis cualitativo asistido por ordenador con Atla Ti. In: Izquierdo C, Perinat A. (Eds.) Investigar en psicología de la educación. Nuevas perspectivas conceptuales y metodológicas. Barcelona (ES): Amentia, 2011. p. 299-363: [acceso 10 Dic 2013]. Disponible en: https://www.academia. edu/1424153/Analisis_cualitativo_asistido_por_ ordenador_con_ATLAS.ti

14. Badía A, Monereo C, Meneses J. El profesor universitario: identidad profesional, concepciones y sentimientos sobre la enseñanza. VI Congreso Internacional de Psicología y Educación, 2011 Mar 
29-1 Abril; Valladolid, Castilla y León. Valladolid (ES): UvA; 2011.

15. Waldow V. Enseñanza de enfermería centrada en el cuidado. Aquichán-Col. 2009 Dic; 9(3):246-56.
16. Carr G. Changes in nurse education: delivering the curriculum. NEDT. 2008 Jan; 28:120-7.

17. Gallagher P. How the metaphor of a gap between theory and practice has influenced nursing education. NEDT. 2004 May; 24(4):263-68. 